УДК:351

DOI: https://doi.org/10.32689/2618-0065-2019-2/1-66-75

Каршисва Альона Іванівна, докторант Міжрегіональної академії управління персоналом, 03039, вул. Фрометівська, 2, тел.: +380980595924; еmail: alena.200kiev@gmail.com

ORCID: 0000-0001-5544-6796

Шойко Василь Анатолійович кандидат історичних наук, доцент, заступник начальника інституту - головний інженер Українського науководослідного інституту цивільного захисту, м. Київ, вул. Рибальська, 18, 01011, Україна, тел.: (044)-280-18-01, e-mail.: pom_mtz@ukr.net

ORCID: 0000-0001-8670-8779

\title{
ОСНОВИ ДЕРЖАВНО-ПРАВОВОГО РЕГУЛЮВАННЯ МЕДІАЦІї
}

Анотація. Стаття присвячена розгляду основ державно-правового регулювання медіації. Розглянута модель медіації, а також підходи до побудови структури медіації та медіаційних процесів. Проаналізовано методологічні засади регулювання медіації та їх реалізацію у сьогоденні. Визначено сфери застосування медіації. Змодельована модель медіації. Доведено, що медіація це процес спільного врегулювання та вирішення конфліктів. Головними складовими іiі $\epsilon$ певні тенденції запровадження медіації в світі, відповідні їм закономірності й, пов'язані з ними, принципи. Запровадження медіації відповідно до вимог, що випливають із розроблених закономірностей і принципів, цілком залежить від конфліктуючих сторін.

Обгрунтовано, що тенденції розвитку медіаційної угоди визначаються розвитком i функціонуванням державного регулювання та соціальними процесами в суспільстві. Але головним фактором, що впливає на запровадження медіації, є державно-правова система, яка віддзеркалює всі явища, що відбуваються у державі та за ії межами.

Визначено, що медіація $\epsilon$ тією рушійною силою, яка націлена на вирішення спорів. Тому в державно-правовій системі потрібно розвивати й успішно застосовувати для досягнення мирного регулювання спорів

Ключові слова: державно-правове регулювання медіації, медіатор, принципи сторін, альтернативне вирішення спорів, процес, конфлікт сторін, спір, медіаційна угода. 
Karshyieva Alona Ivanivna, $\mathrm{PhD}$ student, Interregional Academy of Personnel Management, 03039, st. Frometivska, 2, tel .: +380980595924; email: alena.200kiev@gmail.com

ORCID: 0000-0001-5544-6796

Shoyko Vasyl Anatoliyovych Candidate of Historical Sciences, Associate Professor, Deputy Head of the Institute - Chief Engineer of the Ukrainian Research Institute of Civil Protection, Kyiv, ul. Rybalska, 18, 01011, Ukraine, tel .: (044) 280-18-01, e-mail: pom_mtz@ukr.net

ORCID: 0000-0001-8670-8779

\title{
FUNDAMENTALS OF STATE-LEGAL REGULATION OF MEDIATION
}

\begin{abstract}
The article is devoted to consideration of the basics of state-legal regulation of mediation. The model of mediation, as well as approaches to building a mediation structure and mediation processes are considered. The methodological bases of regulation of mediation and their realization in the present are analyzed. Areas of application of mediation are defined. Simulated mediation model. It is proved that mediation is a process of joint regulation and conflict resolution. Its main components are some trends in the implementation of mediation in the world, the corresponding laws and related principles. The introduction of mediation in accordance with the requirements arising from the developed laws and principles, entirely depends on the conflicting parties

It is substantiated that tendencies of mediation agreement development are determined by the development and functioning of state regulation and social processes in society. But the main factor that influences the introduction of mediation is the state-legal system, which reflects all the phenomena occurring in the state and beyond its borders

It is determined that mediation is the driving force behind dispute resolution. Therefore, the state-legal system needs to be developed and successfully applied to achieve the peaceful regulation of disputes
\end{abstract}

Key words: state-legal regulation of mediation, mediator, party principles, alternative dispute resolution, process, conflict of parties, dispute, mediation agreement.

Постановка проблеми. Актуальність теми зумовлена необхідністю подальшого розвитку медіації в інформаційному суспільстві в контексті завдань, які висувають в системі державно-правового регулювання. На сучасному етапі розвитку державно-правовій системи в Україні особливої ваги набирає проблема запровадження медіації в Україні При проведенні 
судової реформи згадки про медіацію та медіаторів було включено в процесуальні кодекси, а медіація була визначена як соціальна послуга

Аналіз останніх публікацій за проблематикою. Процес медіації грунтовно розглянутий в роботах Р. Буша, Д. Фолджер, Д. Голан, М. Вільямс, Д. Фолджерем, Д. Хоффман, Л. Ріскіном, Р. Бернсом, С. Ярошенко, Я. Михайленко, Ю. Шешуряк та ін. Медіаційний поцес вони розглядають як цілеспрямовану узгоджену взаємодоповнюючу систему дій керуючої i керованої підсистем для досягнення поставленої мети. Тенденції до впровадження медіації у правовій простір Україні не $\epsilon$ новими - вони активно запроваджені в Указі Президента України №361/2006 від 10.05.2006 «Про концепцію вдосконалення судівніцтва для утвердження справедливого суду в Україні відповідно до європейських стандартів», де серед інших положень пердбачена необхідність розвитку альтернативних (позасудових) способів врегулюванння та інфорування громадськості про переваги альтернативних (позасудових) способів врегулювання спорів, створення умов для стимулювання дешевших i менш формалізованих способів їх врегулювання та інформування громадськості про переваги таких способів захисту прав порівняно з судовим механізмом, а також зазначено, що звернення до суду бажано використовувати як винятковий спосіб врегулювання юридичних спорів.

У 2014 році Україна підписала Угоду про асоціацію з Європейським Союзом. Згідно зі ст. 1 цієї угоди, Україна і СС мають посилювати співпрацю в сфері правосуддя, свободи та безпеки з метою забезпечення верховенства права та поваги до прав людини i основоположних свобод. Країни Свропейського Союзу погодилися, що забезпечення верховенства права та кращого доступу до правосуддя має включати доступ як до судових, так і до позасудових методів врегулювання спорів.

Крім того, запровадження медіації в Україні включено у План дій щодо імплементації кращих практик якісного та ефективного регулювання, відображених Групою Світового банку у методології рейтингу «Ведення бізнесу» на 2016 рік (п. 9), затверджений розпорядженням Кабінету міністрів України №1406-р від 16.12.2015.

При проведенні судової реформи згадки про медіацію та медіаторів було включено в процесуальні кодекси, а Міністерство соціальної політики України навіть затвердило 17.08.2016 Державний стандарт соціальної послуги посередництва (медіації) №892. Таким чином, медіація була визначена як соціальна послуга, хоча нині діючий Закон «Про соціальні послуги» прямо про неї не говорить. Але вже до нового Закону України «Про соціальні послуги», який набере чинності у 2020 році, медіація включена як базова соціальна послуга.

Формулювання цілей (мети) статті. Здійснення аналізу державноправового регулювання у з метою їі адаптації до суспільно-політичних реалій України. 
Виклад основного матеріалу. Медіація належить до альтернативніх способів розгляду спорів і активно впроваджується в суспільне житття (Р. Буша, Д. Фолджер, Д. Голан, М. Вільямс, Д. Фолджерем, Д. Хоффман, Л. Ріскіном, Р. Бернсом, С. Ярошенко, Я. Михайленко, Ю. Шешуряк та ін.). Такі альтернативні заходи дуже потрібні. Наразі в Україні процедура медіації не регламентована на законодавчому рівні, що ускладнює іiі застосування на практиці

Медіація є доволі актуальною темою для обговорення в українських правових колах. Актуальність теми посилюється и тому, що Європейське співтовариство рекомендує впровадити медіацію i закріпити це на законодавчому рівні як один з основних методів альтернативного вирішення спорів на досудовому етапі або під час судового розгляду

Про актуальність та корисність медіації, необхідність ії закріплення в конкретному законодавчому акті свідчать іï переваги, цілі та завдання. Медіація - це одна із форм посередництва ( alternative dispute resolution ADR) що дозволяє врегулювати конфлікти в самих різних сферах життєдіяльності людини. Медіація широко використовується для вирішення цивільних спорів, конфліктів та незгод.

Медіація пишеться і вимовляється майже однаково на багатьох мовах: англійській, французькій, німецькій, італійській, іспанській, португальській mediation. Медіація також досить вдало і ефективно зарекомендувала себе в сфері бізнесу при вирішенні комерційних конфліктів між різними людьми і організаціями (бізнес-медіація) Слово "медіація" походить від латинського medius, medium, і позначає "посередині".

Медіація - це процес, в якому бере участь неупереджена третя сторона, яка допомагає сперечається або конфліктуючим сторонам розібратися в існуючих між ними розбіжностей, зрозуміти суть проблеми, що виникли і по можливості їх вирішити.

Сфера застосування медіації:

- суперечки і незгоди між членами спільнот і сусідами,

- конфлікти між керівництвом і трудовим колективом,

- спори і конфлікти майнового характеру,

- конфлікти і розбіжності при розділі спадщини,

- сімейні конфлікти,

- проблеми, що виникають при розлученні,

- проблеми при визначенні майбутнього місця проживання дітей після розлучення батьків,

- конфлікти в сфері охорони здоров'я,

- складності взаєморозуміння в освітньому процесі,

А також, різні нерозуміння, розбіжності і конфлікти, які знаходяться в компетенції фахівця - медіатора. Те, як часто, називають медіатора, цілком узгоджується з дослівним перекладом - посередник «що оточує посередині». 
Медіація - це процес спільного (сторін спору і медіатора) врегулювання і вирішення конфлікту, в ході якого двоє або більше учасників за допомогою незалежної третьої сторони або сторін (медіаторів) спілкуються один з одним і знаходять прийнятне для всіх сторін вирішення спору.

Функція медіаторів міститься в тому, щоб допомогти учасникам конфлікту розглянути i вивчити всі можливі варіанти рішення $\mathrm{i}$, як цього можна досягти, щоб знайти рішення, яке задовольняє інтереси всіх сторін, що мають відношення до конфлікту.

\section{Роль медіатора:}

У процесі медіації сторони суперечки диктують умови угоди між собою, а не медіатор. Медіатор допомагає сторонам конфлікту взяти рішення:

- добровільно,

- не відчуваючи тиску (ні 3 боку медіатора, ні 3 боку "напарника по конфлікту") - нейтрально

- усвідомлено,

- виключаючи загрози з будь-чиєї сторони,

- не дозволено впливу і маніпуляцій

Медіація спрямована на врегулювання конфліктів, однак, саме по собі рішення конфлікту ні в якому разі не може бути кінцевою метою медіативного процесу. Якщо передбачуване укладення зачіпає юридичні аспекти, то сторонам конфлікту медіатор радить отримати окремі незалежні консультації юристів та фахівців і тільки після всіх узгоджень може рекомендувати висновок медіативної угоди. Водночас, думки науковців щодо характеристики процесу медіації суттєво різняться. Наприклад, американський дослідник Р. Буш висвітлює декілька ознак розвитку медіації, які отримали такі назви: «Задоволення», «Соціальна справедливість», «Трансформація» та «Подавлення» [1]. У цілому, використання медіації призведе до більш ефективного використання обмежених особистих та суспільних ресурсів вирішення конфліктів. Задоволення як результат медіації підтримують М. Галантер, Д. Голан, М. Вільямс, Д. Хоффман $[2,3,4,5]$. Враховуючи це та беручи до уваги участь медіатора, медіація сприяє визнанню і сприйняттю потреб і проблем сторін процесу. Дана ознака була сформульована Л. Ріскіном та Р. Бернсом [6].

Медіація та судовий процес: "Нове - це добре забуте старе". Так говорить приказка, яка може бути застосована і до медіації Часто процес медіації порівнюють 3 судовим розглядом. Медіація використовується в Європі, Північній Америці (в Південній Америці медіація набуває все більшого поширення), Австралії, Нової Зеландії, Китаї, Японії, Австрії, Польщі, Казахстані, Молдові, Білорусії,Росії та почала запроваджуватись в Україні. У сфері медіації цікавім є досвід Європейського Союзу і насправді корисним для України з кількх причин. По-перше, у переважній більшості випадків це юрисдикції цивільного ( контенетального) права, яке діє і в 
Україні. А по-друге, комерційні та інші практики ділового обороту мають певну схожість із тими, що використовують в Україні [7]. При цьому медіацію розглядають як щось "добре та швидке", а судову процедуру - як "юридичну складову". Такі спрощені судження не сприяють формуванню точного і адекватного уявлення про можливі рішення конфліктів ні 3 підтримкою медіації, ні за допомогою судових органів. Результати медіації можуть буті самими різніми i, до того ж, вона має ряд обмежень. Конфліктуючі сторони можуть брати участь в судовому процесі замість медіації або синхронно з судовим розглядом.

Медіація відноситься до методів вирішення конфліктів, так само як переговори і арбітраж. Ця група методів (переговори, медіація, арбітраж) об'єднані в так звану групу способів альтернативного вирішення спорів APC (adr - alternative dispute resolution). «Альтернатива» означає метод врегулювання суперечок, розбіжностей і конфліктів відмінний від судового розгляду. Під альтернативним вирішенням спорів (АРС) розуміється так само адекватне вирішення спорів, так як переговори і медіація часто проводяться паралельно з судовим розглядом Слід виділити, що договори в сфері медіації поділяються на такі, що затверджені в понятті як мірова угода, та такі, що мають статус цивільного правочину [8].

Є. Пушкар зазначав, що "зупинення провадження в справі - це перева в судовому розгляді на невизначений строк у випадках, прямо вказаних в законі. Зупинення провадження в справі виклікається обставинами, які перешкоджаютьрозгляду справи по суті, але не можуть бути усунуті ні судом, ні сторонами, тобто вони не залежать від їх волі... 3 зупіненням провадження в справі припиняється вчинення будь-яких процесуальних дій по даній справі, за незначними винятками (наприклад,дій по забезпеченню доказів)" [9]. Таку ж саму думку висловлює В. Мамницький [9; 10].

Офіційна медіація, будучи міждисциплінарної сферою, базується на теоретичні i практичні напрацювання різних наук (економіка, юриспруденція, перевага, психологія, конфліктологія, соціологія, філософія, психотерапія, психолінгвістика і ін.) I володіє свої принципи, а також ряд обмежень. Це дозволяє окреслити коло компетенції медіатора і беруть участь в конфлікті сторін, а в тому ж дусі визначити суть процесу медіації та коло іiі можливостей. Спираючись на принципи медіації та обмеження процесу медіації, дозволено відрізнити професійну медіацію, яку проводить кваліфікований i навмисне підготовлений фахівець, від неофіційної (неформальній) медіації, якою завідує зацікавлена особа - це може бути один, родич, шеф, авторитетний знайомий.

\section{Основні принципи медіації:}

1. Добровільна участь сторін у процесі (одностайність всіх конфліктуючих сторін і медіатора)

2. Неупередженість (не плутайте з байдужістю або невтручанням) 
3. Розкриття медіатором суті конфлікту (можливий конфлікт інтересів 3 позиції кожної спорящей боку)

4. Наділення конфліктуючих сторін силою, владою, для здатності прийняти самостійне усвідомлене рішення (інформування про можливі варіанти рішень i їх наслідків з усіх ймовірних позицій)

5. Шанобливе ставлення до особистості беруть участь в конфлікті, їх особливості, дотримання культурних, моральних, етичних норм кожного співучасника конфлікту

6. Забезпечення особистої безпеки учасників медіації, повідомлення та захист від можливих ризиків при обговоренні та прийнятті можливих рішень

7. Забезпечення особистої безпеки учасників медіації, інформування від можливих ризиків при обговоренні та прийнятті можливих рішень

8. Конфіденційність отриманої інформації від учасників, як при індивідуальному обговоренні варіантів вирішення, так і в самому процесі медіації

9. Орієнтація співучасників медіації на перспективу подальшого розвитку, в майбутнє, а не розгляд і "заїдання" в минулому

10.Акцентування і облік взаємних інтересів і потреб усіх співучасників конфлікту (в тому числі недієздатних, інвалідів, дітей), а не прав окремих людей

11.Привілейованість юридичного боку винесеного рішення (в разі прийняття медіативного угоди - воно неодмінно для виконання учасниками медіації)

12.Компетентність і професіоналізм медіатора в обстежуваних питаннях при вирішенні конфліктів (наявність у медіатора спеціальних знань і умінь, пов'язаних з областю розгляду конфліктів)

Вважається , що успішні результати медіації значною мірою залежать від чіткого поетапного слідування процессу, при цьому перехід до наступного етапу повинен відбуватися після досягнення цілей на попередньому. Втім, етапи та принципи медіації законодавством України не регулюються, хоча давно розроблені та практикуються світовою спільнотою медіаторів [11]. Розвиток до впровадження медіації у правову сферу в Україні не є новими вони запроваджені в Указі Президента України №361/2006 від 10.05.2006 «Про концепцію вдосконалення судівніцтва для утвердження справедливого суду в Україні відповідно до європейських стандартів», де серед інших положень передбачена необхідність розвитку альтернативних (позасудових) способів врегулюванння та інфорування громадськості про переваги альтернативних (позасудових) способів врегулювання спорів, створення умов для стимулювання дешевших i менш формалізованих способів їх врегулювання та інформування громадськості про переваги таких способів захисту прав порівняно з судовим механізмом, а також зазначено, що звернення до суду бажано використовувати як винятковий спосіб врегулювання юридичних спорів. 
Указом Президента України №597/2011 від 24.05.2011 «Про Концепцію розвитку кримінальної юстиції щодо неповнолітніх в Україні» впроваджується новий інститут для кримінального права України - інститут відновного правосуддя (щодо неповнолітніх) i звертається увага на необхідність сприяння розвитку програм відновного правосуддя щодо неповнолітніх, які вчинили правопорушення, шляхом запровадження процедури медіації як ефективного засобу добровільного примирення потерпілого та правопорушника.

Згадується про процедуру медіації і в Законі України «Про безоплатну правову допомогу». Зокрема, ст. 7 цього Закону передбачає, що одним 3 видів послуг з надання первинної безоплатної правової допомоги в Україні є надання допомоги в забезпеченні доступу особи до вторинної правової допомоги та медіації.

У 2014 році Україна підписала Угоду про асоціацію з Свропейським Союзом. Згідно зі ст. 1 цієї угоди, Україна і СС мають посилювати співпрацю в сфері правосуддя, свободи та безпеки з метою забезпечення верховенства права та поваги до прав людини i основоположних свобод. Країни Європейського Союзу погодилися, що забезпечення верховенства права та кращого доступу до правосуддя має включати доступ як до судових, так і до позасудових методів врегулювання спорів.

Крім того, запровадження медіації в Україні включено у План дій щодо імплементації кращих практик якісного та ефективного регулювання, відображених Групою Світового банку у методології рейтингу «Ведення бізнесу» на 2016 рік (п. 9), затверджений розпорядженням Кабінету міністрів України №1406-р від 16.12.2015.

При проведенні судової реформи згадки про медіацію та медіаторів було включено в процесуальні кодекси, а Міністерство соціальної політики України навіть затвердило 17.08.2016 Державний стандарт соціальної послуги посередництва (медіації) №892. Таким чином, медіація була визначена як соціальна послуга, хоча нині діючий Закон «Про соціальні послуги» прямо про неї не говорить. Але вже до нового Закону України № 4607 «Про соціальні послуги», який набере чинності у 2020 році, медіація включена як базова соціальна послуга [12].

Недарма зараз точиться чимало дискусій щодо реалізації інституту медіації в Україні, адже медіація як процес досудового врегулювання спорів містить багато переваг для сторін на противагу судовому розгляду [13]. Велика Палата Верховного Суду України сформувала позицію «...користуючись нагодою, варто також нагадати, що за своєю правовою природою мирова угода $є$ договором, який укладається сторонами 3 метою припинення спору, на умовах, погоджених сторонами» [14]. 


\section{Jimepamypa:}

1. Буш Р., Фолджер Д. Что может медиация. Трансформативность и подход к конфликту: пер. с англ. Київ, 2007. С. 18 A Settlement Judge, Not a Trial Judge: Judicial Mediation in the United States», 1985

2. Д. Голан («Mediating Legal Disputes: Effective Strategies for Lawyers and Mediators», 1996)

3. М. Вільямс («Can’t I Get No Satisfaction? Thoughts on The Promise of Mediation» Mediation Quarterly, 1997) («Mediation and lawyers», 1982),

4. Д. Фолджерем («The Promise of Mediation: The Transformative Approach to Conflict», 1994

5. Д. Хоффман («Confessions o f a Problem-Solving Mediator» Society for Professionals in Dispute Resolution News», 1999

6. Л. Ріскіном Р. Бернсом «Some Ethical Issues Surrounding Mediation», 2001

7. Ярошенко С. Медіація: конфіденційна та щвидка нейтралізація конфлікту при мінімумі витрат//Закон і Бізнес. Законодавча база.- №15 (1417). - 26.04.2019

8. Михайленко Я. Різновиди медіаційних угод// https://blog.liga.net/ yamikhaylenko/article/33695 - 14.06.2019

9 Цивільне процесуальне право України: підручник/за ред. В.В. Комарова. Харків: Право, 1999. 592с.) с. $279-280$

10. Курс цивільного процесу: підручник / В.В.Комаров, В.А. Бігун, В.В. Баранкова та ін. ; за ред. В.В. Комарова. Харків: Право, 2011. 1352 с. ) с. 609

11. Шешуряк Ю. Застосування правіл класичної медіації в нотаріальній практиці// Нотаріат України. - №1 (32). - 24.04.2019

12. Закон України про соціальні послуги № 4607/ https://zakon.rada.gov.ua

13. Макаренко С. Закон про медіацію: нереальна реальність // Юридична газета. - 18 вересня 2018 p.

14. ВП ВС, справа № 910/12230/16, 11.12718. Мирова угода може бути затверджена під час касаційного перегляду судового рішення, зокрема й при розгляді справи Великою Палатою Верховного Суду // https://protocol.ua

\section{References:}

1. Folger, J. P., Bush, R. A. B. (2007). Chto mozhet mediatsiya. Transformativnost $i$ podkhod k konfliktu [The Promise of Mediation. Transformative Approach to Conflict]. Kyiv [in Russian].

2. Galanter, M. (1985). A Settlement Judge, Not a Trial Judge: Judicial Mediation in the United States. Institute for Legal Studies, University of Wisconsin Law School [in English].

3. Golann, D., Aaron, M. C. (1996). Mediating Legal Disputes: Effective Strategies for Lawyers and Mediators. Little, Brown [in English].

4. Williams, M. (1997). Can’t I Get No Satisfaction? Thoughts on The Promise of Mediation. Mediation Quarterly, 15(2), 143-154 [in English]. English].

+ Riskin, L. L. (1982). Mediation and lawyers. Ohio State Law Journal, 43, 29-60 [in

5. Folger, J. P., Bush, R. A. B. (2004). The Promise of Mediation. Transformative Approach to Conflict. Jossey-Bass [in English].

6. Hoffman, D. A. (1999). Confessions o f a Problem-Solving Mediator. Society for Professionals. Dispute Resolution News, 23(3), 1-4 [in English].

7. Burns, R. P. (2001). Some Ethical Issues Surrounding Mediation. Fordham Law Review, 70(3), 691-717 [in English].

8. Yaroshenko, S. (April 26, 2019). Mediatsiia: konfidentsiina ta shchvydka neitralizatsiia konfliktu pry minimumi vytrat [Mediation: confidential and rapid neutralization of the conflict with minimal expenses]. Zakon i Biznes. Zakonodavcha baza - Law and Business. Legislative 
base, 15(1417). Retrieved from http://evris.law/uk/stattja-mediacija-konfidencijna-ta-shvidkanejtralizacija-konfliktu-pri-minimumi-vitrat/ [in Ukrainian].

9. Mykhailenko, Ya. (June 14, 2019). Riznovydy mediatsiinykh uhod [Variety of Mediation Agreements]. blog.liga.net. Retrieved from https://blog.liga.net/user/yamikhaylenko/article/33695 [in Ukrainian].

10. Komarov, V. V. (Eds.). (1999). Tsyvilne protsesualne pravo Ukrainy [Civil Procedural Law of Ukraine]. Kharkiv: Pravo [in Ukrainian].

11. Komarov, V. V., Bihun, V. A., Barankova, V. V. (2011). Kurs tsyvilnoho protsesu [Civil process course]. Kharkiv: Pravo [in Ukrainian].

12. Sheshuriak, Yu. (April 24, 2019). Zastosuvannia pravil klasychnoi mediatsii v notarialnii praktytsi [Application of Rules of Classical Mediation in the Notary Practice]. Notariat Ukrainy - Notary of Ukraine, 1(32). Retrieved from http://journal.npu.org.ua/2019/mediator/ [in Ukrainian].

13. Zakon Ukrainy "Pro sotsialni posluhy" : vid 17.01.2019, № 4607 [Law of Ukraine “On Social Services” from 17.01.2019, № 4607]. (n.d.). zakon.rada.gov.ua. Retrieved from https://zakon.rada.gov.ua/laws/show/2671-19 [in Ukrainian].

14. Makarenko, Ye. (September 18, 2018). Zakon pro mediatsiiu: nerealna realnist [The law on mediation: an unreal reality]. yur-gazeta.com. Retrieved from http://yurgazeta.com/publications/practice/mizhnarodniy-arbitrazh-ta-adr/zakon-pro-mediaciyu-nerealnarealnist.html [in Ukrainian].

15. VP VS, sprava № 910/12230/16, 11.12718. Myrova uhoda mozhe buty zatverdzhena pid chas kasatsiinoho perehliadu sudovoho rishennia, zokrema y pry rozghliadi spravy Velykoiu Palatoiu Verkhovnoho Sudu [Grand Chamber of the Supreme Court. Case № 910/12230/16, 11.12718. The peace agreement may be approved during the cassation review of the court decision, in particular, when considering the case by the Grand Chamber of the Supreme Court]. verdictum.ligazakon.net. Retrieved from https://verdictum.ligazakon.net/document/78715780 [in Ukrainian]. 